\title{
Prospects and limitations of heavy mineral analyses to discriminate preglacial/glacial transitions in Pleistocene sedimentary successions
}

\author{
Tomasz Zieliński \\ Institute of Geology, Adam Mickiewicz University, Krygowskiego 12, 61-680 Poznań, Poland, e-mail: zielu@amu.edu.pl
}

\begin{abstract}
The present study revolves around the identification of the stratigraphical boundary between Pleistocene formations that formed prior to the first advance of the Scandinavian ice sheet (Early Pleistocene, i.e., the so-called preglacial) and the overlying, glacially derived deposits (Middle Pleistocene). In particular, it focuses on variation in heavy mineral assemblages, which are an important tool for stratigraphers. The Neogene basement, described here, was most often the source of material that was redeposited by Early Pleistocene rivers. The geological structure and Early Pleistocene palaeogeographical scenarios for various Polish regions are discussed. Moreover, comparisons with other European preglacial formations are carried out. The mineral spectrum of Lower Pleistocene deposits is largely dependent of rocks of the Neogene and Mesozoic basement. If the incision of ancient catchments was into terrigenous rocks, the stratigraphical boundary between preglacial and glacial formations is easily determined with the help of a heavy mineral analysis. As a rule, this coincides with a noticeable change from resistant to non-resistant mineral associations. Such cases are noted for successions in central Poland and eastern England. On the other hand, outcrops of igneous or metamorphic rocks exist within preglacial river catchments in most parts of Europe. They were the local sources of non-resistant heavy minerals long before their glacial supply from the Baltic Shield. In these cases, mineralogical analysis fails in the search for the Early/Middle Pleistocene transition.
\end{abstract}

Key words: river networks, fluvial deposits, stratigraphy, Early Pleistocene, Poland

\section{Introduction}

What is the meaning of the term preglacial? This stratigraphical phrase was introduced into the geological literature in the first half of the nineteenth century by Lewiński (1928). In doing so, he defined a series of sands, gravelly sands and silts that had been noted in central Poland as overlying Paleogene and Neogene rocks and being covered by glaciogenic deposits containing Scandinavian erratics. In preglacial deposits, Scandinavian components are missing. This means that the preglacial formation represents the Early Pleistocene, predating the first Scandinavian glaciation, i.e., corresponding to the timespan of approximately 2.6-0.8 Ma. In this, stratigraphical units from the Pretiglian to Bavelian are equivalents. Lower Pleistocene deposits are recorded in Poland and central Europe in fluvial and lacustrine facies, while in western Europe fluvial and fluvio-marine predominate (Bujak et al., 2016; Griffioen et al., 2016; Marks et al., 2016 and references therein). The general European fluvial network of that time is relatively well known (Fig. 1), however it still needs further detailed researches.

Originally, the stratigraphical interpretation of preglacial deposits was based on petrographic analysis of gravels (Lewiński, 1928). However, the problem was that this formation frequently contains 


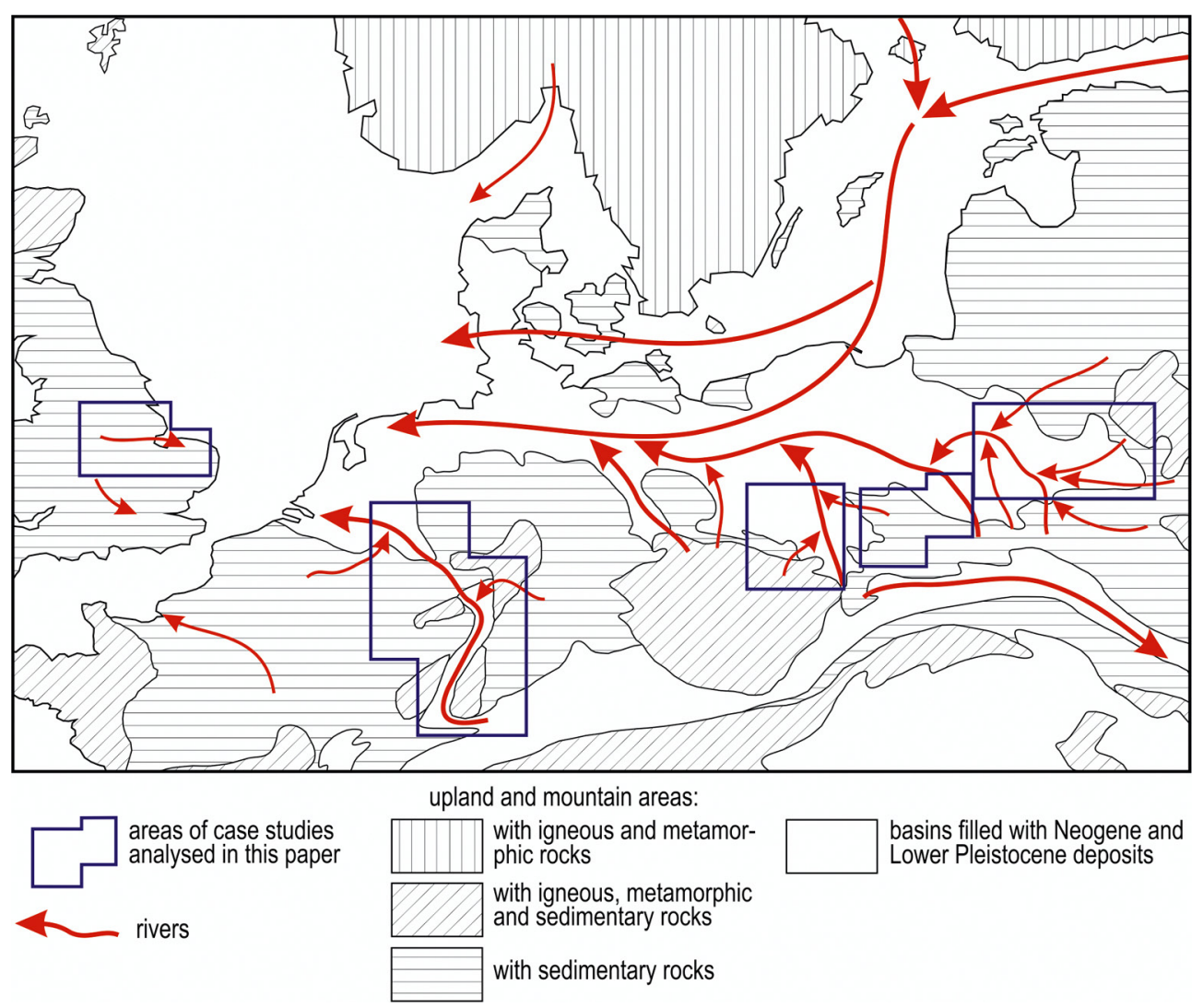

Fig. 1. Palaeogeography of Europe during the Neogene/Quaternary transition (data from Czerwonka \& Krzyszkowski, 2001; Piwocki et al., 2004; McCann, 2008; Gibbard \& Lewin, 2016).

exclusively sandy successions which cannot be analysed in this way. The same goes for the usefulness of a classic biostratigraphical method, i.e., pollen analysis. This is applicable only to dating of lacustrine deposits; such are relatively rare in the Lower Pleistocene. Increasingly, methods of absolute dating are being used in recent studies, including optically stimulated luminescence OSL and TT-OSL, electron spin resonance ESR and ESR/U (Cordier et al., 2012; Antoine et al., 2015; Duval et al., 2015; Gao et al., 2017) and palaeomagnetics (Chiarini et al., 2009; Roquero et al., 2015; Bolikhovskaya et al., 2016). However, these analyses are expensive, results often questionable and resolution is very low for such old deposits (compare Westgate et al., 2013; Arnold et al., 2015). As a result, the traditional mineralogical analyses of sand-sized deposits are still being done (e.g., Bujak, 2010; Pirkle et al., 2013; Griffioen et al., 2016; Szujó et al., 2017). In this method the emergence of feldspars and non-resistant heavy minerals in successions is recognised as the identifier of the first advance of the ice sheet, i.e., marking the boundary between the Lower and Middle Pleistocene. Both sand components are genetically related with igneous and metamorphic rocks transported from the Scandinavian Shield by the ice sheet.
The aim of the present note is to compare heavy mineral assemblages of Lower Pleistocene deposits from various parts of Poland, as well as from some sites in western Europe for which the geological background of preglacial formations, i.e., outcrops of Mesozoic and Palaeozoic rocks, are presented. Moreover, scenarios for Early Pleistocene palaeogeography of these regions are discussed. As a result, an answer to the basic question is supplied: which parts of Poland and Europe are especially predestined for using heavy mineral analysis as a stratigraphical tool in studies of the boundary between preglacial and glacial formations?

\section{Weathering of pre-Quaternary local basement $v$ s glacial supply of Scandinavian rocks: two opposite sources of heavy minerals within preglacial deposits}

\subsection{Neogene basement}

The maximum thickness of Neogene deposits in Poland (over 200, or even $300 \mathrm{~m}$ ) has been noted 
in the central Polish Lowlands and in the Sudetic Foreland. Late Miocene and Pliocene subsidence was the most intensive in these areas. In general, Neogene deposits are absent in northern Poland, as a result of later glacial erosion (Piwocki et al., 2004). Neogene facies, in contrast to Paleogene ones, are of terrestrial origin, having formed in fluvial and lacustrine environments. Shallow-marine and brackish facies of Miocene age are restricted to western and southern Poland. It is assumed that the climate was warm and humid during the Miocene (Piwocki et al., 2004) and temperate and humid during the Pliocene (Stuchlik, 1987). The stratigraphical subdivision of the Neogene succession into Miocene and Pliocene systems is very difficult and controversial even to the present day. The lithological variability of the Polish Neogene is quite minor, and therefore heavy minerals play an important, often crucial role as a stratigraphical tool (Czerwonka \& Krzyszkowski, 2001).

Which Neogene formations could have been the source of sediments that were redeposited during the Early Pleistocene to form preglacial alluvia? The options are as follows:

The Adamów Formation is dated as Middle to Late Miocene (Ciuk, 1970; Piwocki \& Ziembińska-Tworzydło, 1997). These deposits occur in central Poland and in the Sudetic Foreland and comprise mainly sands with subordinate gravels and silts, containing brown coal detritus. They were deposited by fluvial systems that flowed from the south to the north, most probably to the main European fluvial artery, i.e., the Baltic River. It drained eastern Scandinavia, then flowed through northern Germany and Denmark towards the Netherlands (Bijlsma, 1981). As noted, these deposits are only residually preserved in northern Poland as a result of subsequent glacial abrasion. The Adamów Formation is characterised by the presence of most resistant heavy minerals such as zircon, rutile, tourmaline and titanite (Piwocki et al., 2004).

The Poznań Formation attains a thickness of 150 $\mathrm{m}$ or more and is mostly located in central Poland. Clay and silt prevail in this unit; however, thick lithosomes of sands have been found as well (Widera, 2007). Originally, these deposits were interpreted as the facies of a very large lake, but now they are regarded as a broad alluvial plain of anastomosed fluvial systems (Widera et al., 2017). The age of the Poznan Formation is assumed to be Middle Miocene to Early Pliocene (Table 1).

The Gozdnica Formation has been found both in the Sudetic Foreland and the Silesian Lowland. Close to the Sudetes Mountains gravels prevail; in a northerly direction, these pass into sands. Deposits
Table 1. Stratigraphical position of Lower Pleistocene and Neogene formations discussed in the text (data from Piwocki et al., 2004; Boenigk \& Frechen, 2006; Kemna, 2007; Lee, 2009).

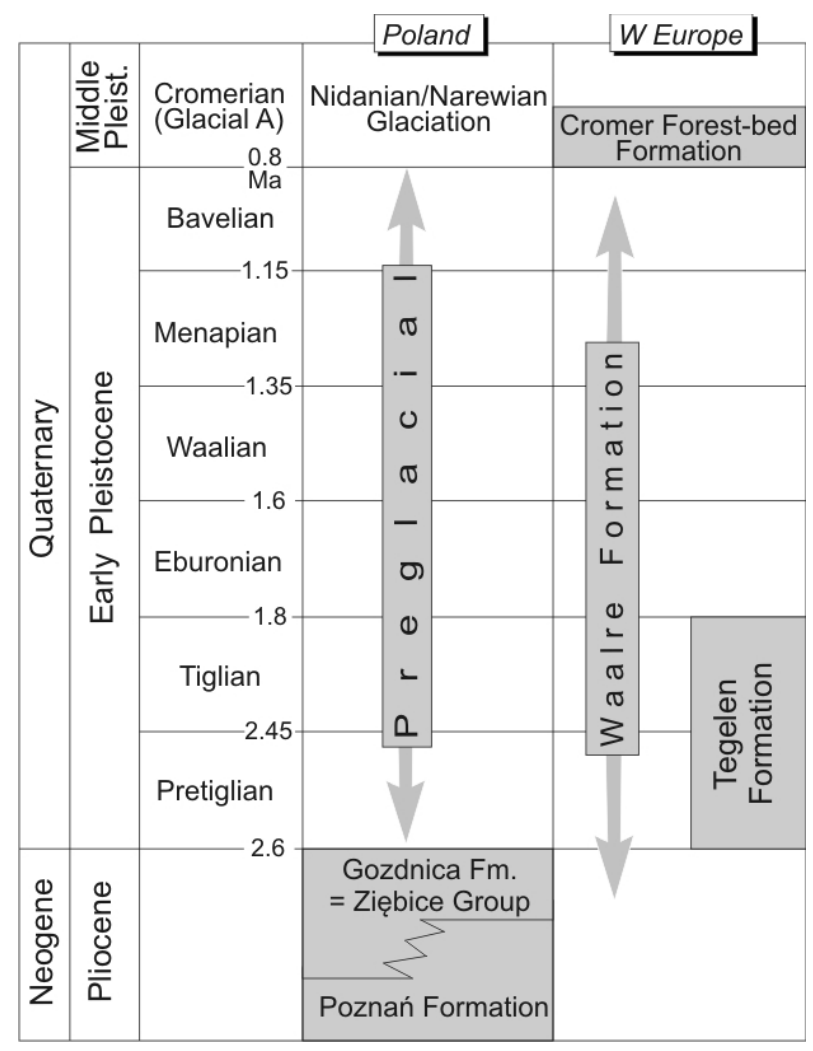

attain up to $80 \mathrm{~m}$ in thickness. The age of this formation is considered to be Pliocene to Early Pleistocene (Table 1). These are alluvia of Sudetic pre-rivers that flowed northwards and then turned to the west, towards the North Sea (Badura \& Przybylski, 2004; Piwocki et al., 2004). For this reason the Gozdnica Formation could only have been the source of Lower Pleistocene sediments in western Poland. Czerwonka \& Krzyszkowski (2001) qualified these deposits as the Ziębice Group and found eight fluvial arteries in the ancient catchment.

The heavy mineral spectrum in the Quaternary substratum of central Poland, i.e., in Neogene deposits, is characteristic. Tourmaline, staurolite and kyanite prevail and the frequency of zircon and rutile is not much lower (Krzyszkowski \& Winter, 1996; Piwocki et al., 2004; Goździk et al., 2010; Goździk \& Zieliński, 2017). It is evident that all these minerals are highly resistant to both physical and chemical weathering (compare Bateman \& Catt, 2007; Racinowski, 2010; Marcinkowski \& Mycielska-Dowgiałło, 2013). The mineral maturity of Neogene sands is most likely the result of long-lasting redeposition of sands, sandstones and marly sandstones of the Lower and lowermost Upper Cre- 


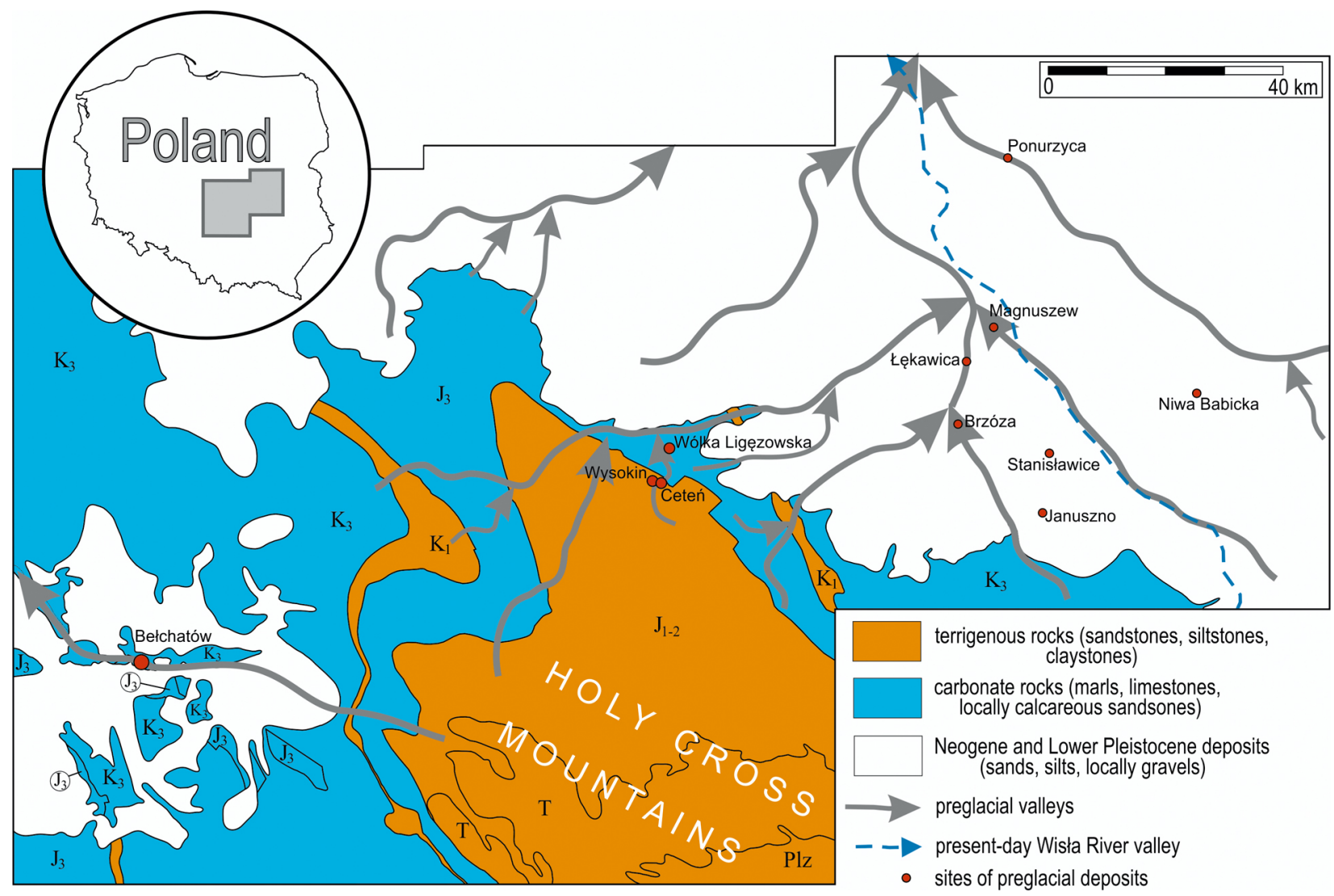

Fig. 2. The southern margin of the preglacial basin in central Poland. Mesozoic terrigenous rocks were the source material for fluvial redeposition during both the late Neogene and Early Pleistocene. Stratigraphical symbols: Plz - Palaeozoic, T - Triassic, J - Jurassic, K - Cretaceous.

taceous (Berriasian to Turonian), Middle and Upper Jurassic (Aalenian-Kimmeridgian) and Lower Jurassic (Hettangian-Toarcian). These rocks crop out in the northern Mesozoic foreground of the Holy Cross Mountains. Meaningful is also the fact that the Holy Cross Mountains consist entirely of sedimentary rocks (Fig. 2). It is worth noting that terrigenous rocks (mostly sandstones), not carbonate ones, are the source of heavy minerals. Recurrence of redeposition processes seems likely during the Mesozoic. For example, the area of the Holy Cross Mountains was an elevated land mass throughout the entire Cretaceous. Grains for Cretaceous sandstones derived therefore from weathering outcrops of terrigenous Jurassic rocks. As a consequence, the 'parent' material for Neogene sands had already been mature in mineralogical terms.

\subsection{Preglacial deposits}

Preglacial deposits of Early Pleistocene age in central Poland represent a stable heavy mineral assemblage. A review of data presented by Sarnacka (1978), Krzyszkowski (1990), Mojski (2005), Bujak
(2010), Roman (2010) and Goździk \& Zieliński (2017) allows the predominant minerals to be listed: tourmaline, staurolite, garnet and zircon (each of them in $10-30 \%$ frequency). Rutile and kyanite are secondary $(5-10 \%)$. Clearly, this mineral spectrum is almost the same as the one in Neogene formations. This is simply due to the fact that the Miocene-Pliocene deposits usually underlie the preglacial sands or crop out in proximity, so they underwent fluvial redeposition during the Early Pleistocene. A distinct mineral change is noted within successions that document the boundary between the Lower and Middle Pleistocene, i.e., at the time of the first advance of the ice sheet to the territory of present-day Poland. Formerly predominant resistant minerals are replaced by non-resistant ones such as amphibole, pyroxene and epidote, that are genetically connected with igneous and metamorphic Scandinavian rocks. A good example is the mineral succession of stratigraphical units from the Neogene up to the start of the Middle Pleistocene, i.e., the first glaciation (Nidanian $=$ Glacial $\mathrm{C})$, found in deposits exposed at the Bełchatów lignite mine (Fig. 3).

This clear and consistent model of mineralogical changes in deposits of the transition between the 


\section{Middle Pleistocene - Nidanian/Glacial A}

\section{Early Pleistocene - preglacial}

Fig. 3. Comparison of heavy mineral spectra from sandy deposits of different age studied in the Bełchatów lignite mine. The Neogene and Early Pleistocene assemblages are similar to each other, whereas the Middle Pleistocene one is clearly different on account of glacial supply of low-resistant minerals (based on Krzyszkowski, 1990; Krzyszkowski \& Winter, 1996; Goździk et al., 2010 and Goździk \& Zieliński, 2017).

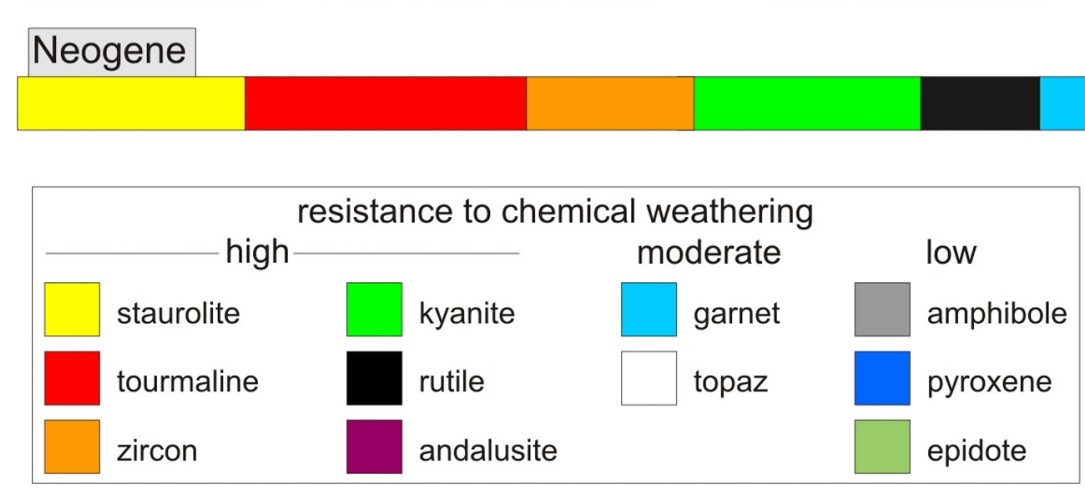

Neogene and Pleistocene concerns the area of central Poland, i.e., the pre-Wisła River catchment and, in particular, its western and southern tributaries. The matter becomes more complex further east. Already during the last century, Kosmowska-Ceranowicz (1979) noted that deposits of fossil preglacial valleys in the central part of the pre-Wisła basin were mineralogically the same as the upper intervals of the Neogene Poznan Formation. On the other hand, the ancient rivers reaching this catchment from the east and northeast (from the area of present-day Belarus) transported and deposited considerable amounts of hornblende (amphibole) which is absent from the basement of central Poland. This is undoubtedly caused by sediments that were transported from Precambrian igneous and metamorphic outcrops located on the Belarusian Ridge to the southwest of the Minsk area (Fig. 4). They were most likely eroded in the upper reaches of preglacial valleys and in this way supplied the catchment with 'fresh' non-resistant minerals. Another mineralogical feature of preglacial deposits was noted by Sarnacka (1978), who found that preglacial sands of southeasterly tributaries of the pre-
Fig. 4. The western Belarus and northeastern Polish part of the Mid-European preglacial catchment. Late Neogene and Early Pleistocene rivers transported material derived both from Cretaceous sedimentary rocks and Precambrian igneous/metamorphic ones. The network of Belarus palaeovalleys is based on Mahnac (2002).

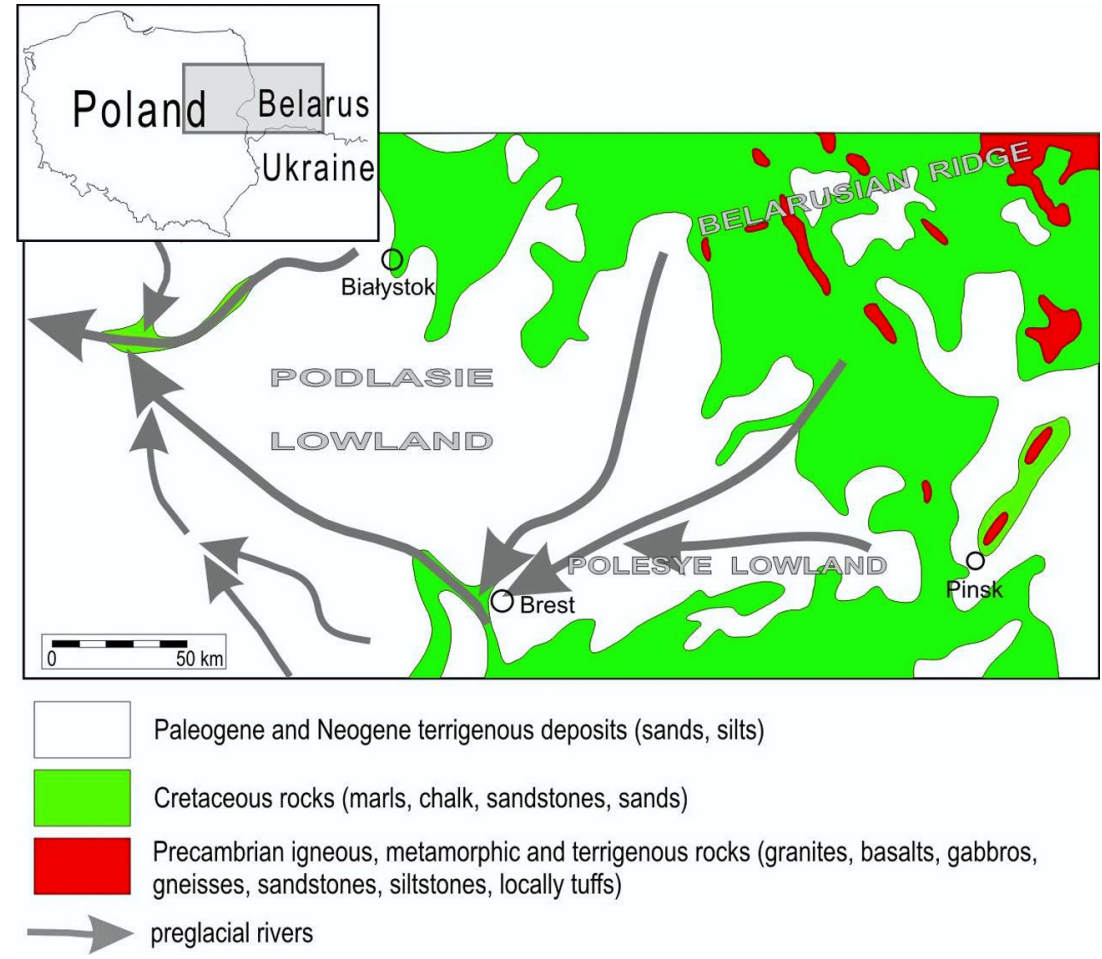




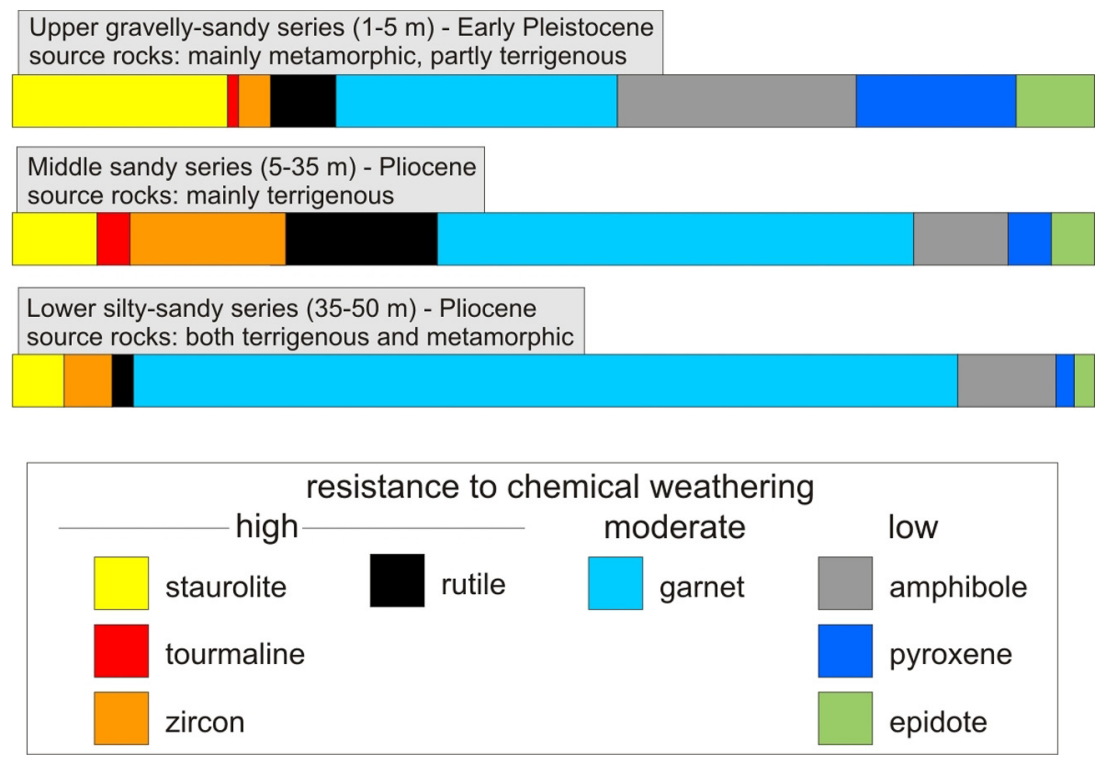

Fig. 5. Heavy mineral assemblages of three successive series of the Łambinowice sequence in the eastern Sudetes Foreland (based on Badura \& Przybylski, 2004). Each mineral spectrum is different due to the catchment changes during the Pliocene - Early Pleistocene timespan.

Wisła River were dominated by zircon. This component derived most likely from redeposition of wide outcrops of Upper Cretaceous sandstones in eastern Poland (Lublin Polesye Upland) and/or in western Ukraine (Volhynian Upland). It is possible that this southeastern fluvial system transported the material derived from a more easterly area, i.e., from granite and migmatite outcrops of the Zhytomyr crystalline basement. All these rocks form the potential source area for the preglacial catchment. These ancient rivers supplied their deposits to eastern Poland and further towards north-central Poland. For this reason the preglacial deposits located to the north and west of Warsaw contain significant amounts of non-resistant heavy minerals such as amphiboles and pyroxenes (Bujak, 2010).

An even more complex situation is found in southwestern Poland where the source area for preglacial deposits was the Sudetes, those block-faulted mountains of a complex geology where outcrops of fairly different rocks form a mosaic-like pattern. These underwent intensive upthrust during the Miocene and since then they have been supplying the fluvial systems of western Poland. Tectonic activity in the Sudetes continued to the Late Pleistocene. As a result, even at the same sites, successive fluvial series were deposited by rivers that drained different mountain catchments (Badura \& Przybylski, 2004). A good example is a sedimentary succession at Łambinowice (eastern Sudetes Foreland) that represents the Neogene to Pleistocene timespan (Fig. 5). The two lower series are of Pliocene age but their heavy mineral assemblages are incomparable. This is related to the fact that the ancient river that transported debris derived from terrigenous rocks deposited alluvium rich in highly resistant minerals, whereas deposits of rivers that drained terrigenous and metamorphic massifs are dominated by garnet. During the Early Pleistocene the drainage network was rebuilt and a 'new' fluvial system started to be fed by material from outcrops of metamorphic rocks in the western Sudetes (Badura \& Przybylski, 2004). This led to a marked change of heavy mineral assemblage (an evidently higher percentage of low-resistant components) (Fig. 5). For this reason in the Łambinowice succession it is impossible to establish the stratigraphical boundary between the Early and Middle Pleistocene on the basis of mineralogical features, contrary to the Bełchatów site (see Fig. 3).

Another convincing example is supplied by the mineralogical composition of the Sudetic alluvia that formed at the same time, during the Neogene/ Pleistocene transition, but in different catchments. Czerwonka \& Krzyszkowski (2001) analysed the heavy mineral assemblages of deposits of four preglacial valleys in the forelands of the central and eastern Sudetes. They found that, although all deposits studied belonged to the same Ziębice Group, their mineral spectra were quite different (Fig. 6). Each ancient river drained another massif that consisted of different rocks. Moreover, there is no substantial mineral change between the preglacial deposits of the Lower Pleistocene and glaciogenic deposits of the Middle Pleistocene in the Sudetic Foreland. In spite of the fact that at a few sites non-resistant amphibole and andalusite predominate in glaciogenic deposits, most often such strata show a predominance of resistant minerals (sillimanite, kyanite, tourmaline, zircon), thus being atypical of 'fresh' glacial supply (compare Czerwonka \& Krzyszkowski, 2001; Fig. 3). 

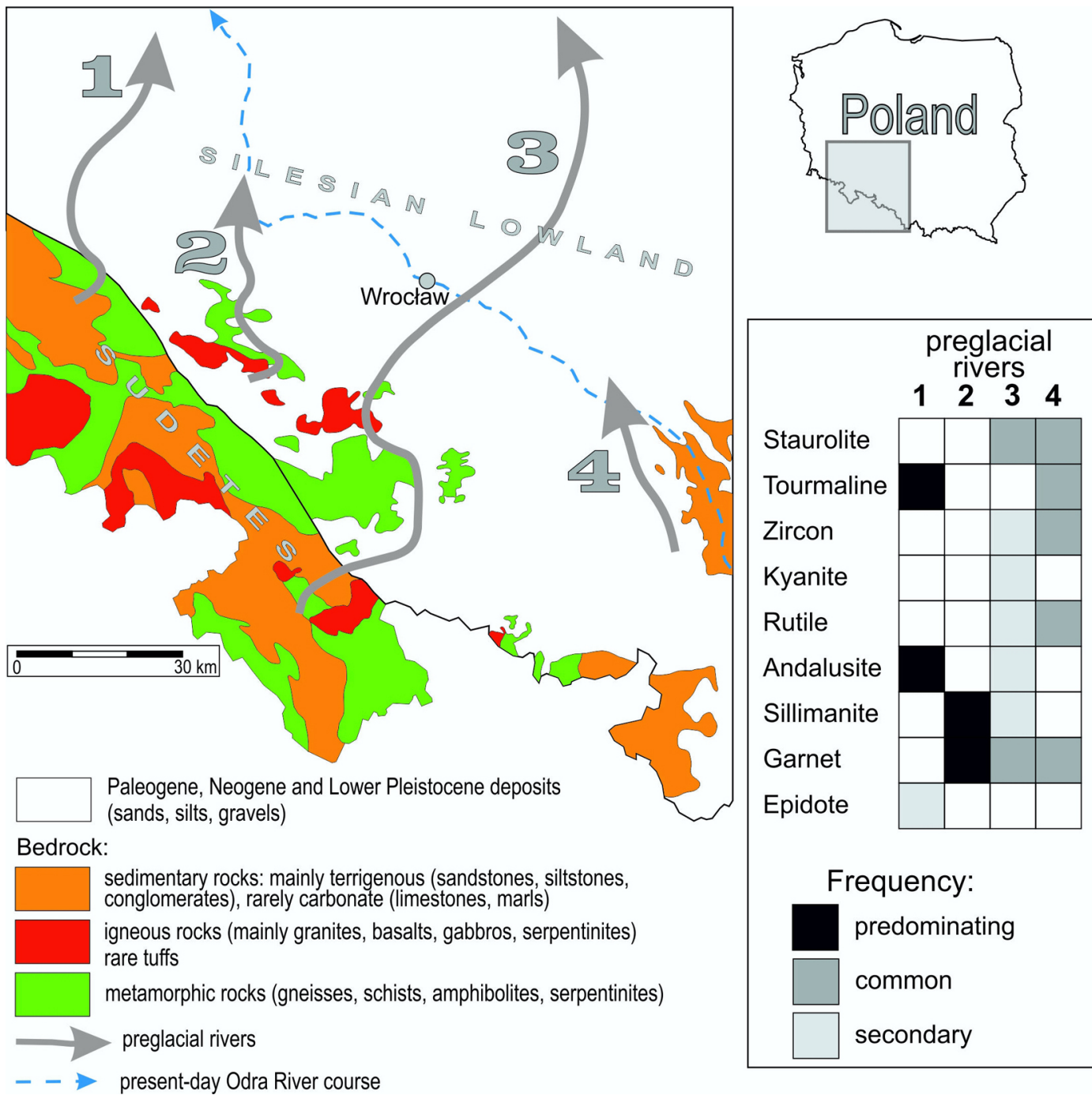

Epidote

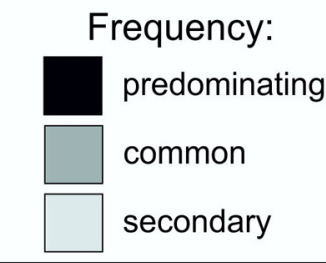

Fig. 6. Geological sketch of Sudetes Mountains, their foreland and Silesian Lowland with four preglacial fluvial tracts during the Early Pleistocene ( $3^{\text {rd }}$ member of Ziębice Group = Pretiglian; data by Czerwonka \& Krzyszkowski, 2001). The deposits of each preglacial river are characterised by a different heavy mineral spectrum because of different geology of their catchments.

\section{Comparison of Polish preglacial deposits with western European ones}

Research of Lower Pleistocene deposits in central Poland has confirmed the utility of heavy mineral analysis for the stratigraphical distinction between preglacial and glacial formations (Sarnacka, 1978; Krzyszkowski, 1990; Bujak, 2010; Roman, 2010; Goździk \& Zieliński, 2017). A fundamental requirement for the applicability of this method is the presence of two different source areas of deposits that were resedimented into the basin studied: the first must have been formed of terrigenous sedimentary rocks and the second of igneous and/or metamorphic ones. During the initial (preglacial) phase the basin witnesses supply of sedimentary rocks by rivers, after which fluvial transport is replaced by glacial supply from areas containing igneous/ metamorphic rocks; only then can the preglacial/ glacial transition be recorded in a distinct change of heavy mineral assemblages (Fig. 7).

These palaeogeographical conditions were not very common in Europe during the Early Pleistocene. A good example is the case of the Lower Rhine Graben, where deposits of the Neogene/ Quaternary transition have been studied in detail: this area can be regarded as the key for stratigraphical models of the Lower Pleistocene in western Europe (compare McCann, 2008). The Neogene deposits are characterised by a stable spectrum of resistant heavy minerals such as zircon, tourmaline, staurolite, rutile and anatase. In contrast, already in the Tegelen Formation (of Pretiglian or Tiglian age; 
fluvial (preglacial)

first phase

of sediment supply

(resistant heavy minerals:

zircon, rutile, tourmaline, staurolite, kyanite, andalusite)

source area

with terrigenous sedimentary rocks glacial second phase

of sediment supply

(unresistant heavy minerals:

amphibole, epidote,

pyroxene, apatite, olivine)

\section{source area}

sedimentary basin with igneous/metamorphic
Fig. 7. Origin of the preglacial to glacial succession. Under such conditions the preglacial and glacial deposits are clearly identifiable in terms of mineralogical features.

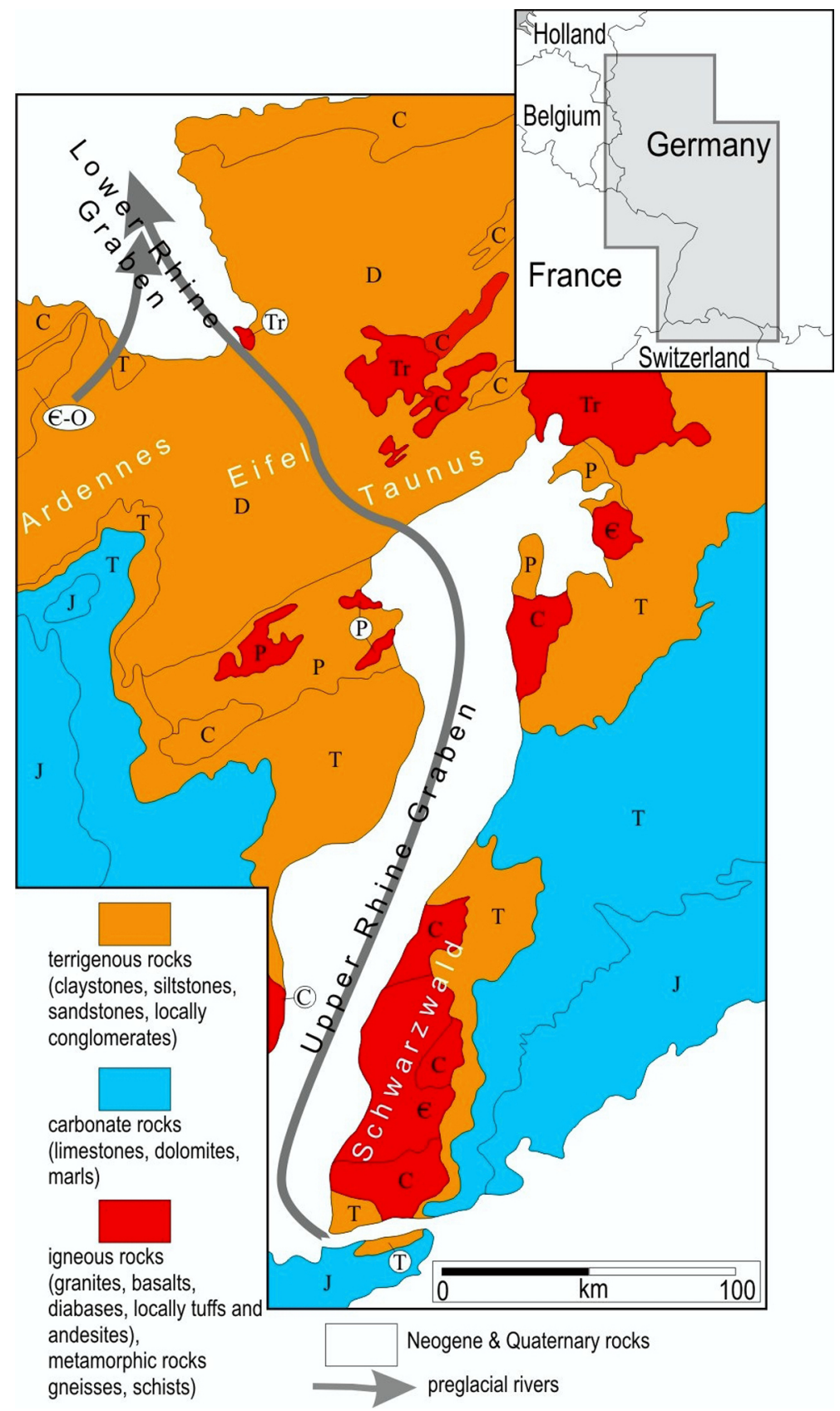

Fig. 8. The pre-Rhine course (long arrow) with a pre-Meuse tributary (short arrow) (based on Kemna, 2008; Westerhoff et al., 2008). Numerous outcrops of igneous/metamorphic rocks supplied the preglacial fluvial system with non-resistant minerals. Stratigraphical symbols: $C$ - Cambrian, O - Ordovician, D - Devonian, C - Carboniferous, P - Permian, T - Triassic, J - Jurassic, Tr - Palaeogene and Neogene. 


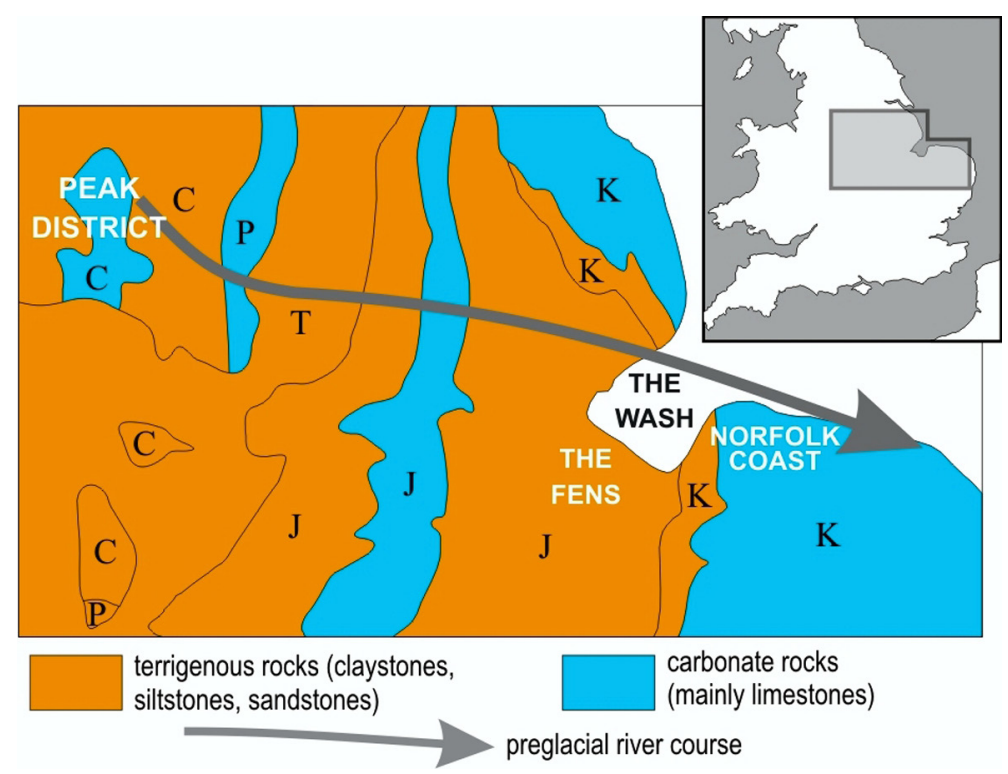

Fig. 9. Preglacial river courses in central and eastern England prior to the first advance of the ice sheet (Lee, 2009). Palaeozoic and Mesozoic sandstones were the main source of heavy mineral assemblage, with a predominance of resistant components.

Table 1), the frequency of non-resistant minerals (epidote, hornblende, garnet) increases distinctly, as a result of the activation of a new fluvial artery that drained the Alpine foreland (Boenigk \& Frechen, 2006). In this way, minerals of igneous and metamorphic rocks were supplied from the Rhenish Massif and the Schwarzwald [Black Forest] Mountains (Fig. 8). Moreover, at the same time the East Meuse [Maas] catchment was incorporated into the Lower Rhine Basin as a source area of minerals associated with metamorphic rocks (Kemna, 2008). Donders et al. (2007) cited the following heavy mineral assemblage of the Waalre Formation which comprises deposits of the Meuse and Lower Rhine fluvial systems of Late Pliocene to Early Pleistocene age (Table 1): garnet, epidote, augite and hornblende. Summing up, in the Rhine catchment the boundary between Lower and Middle Pleistocene deposits cannot be defined on the basis of heavy mineral variability.

The situation is quite different in central and eastern England where preglacial deposits are represented by the Cromer Forest-bed Formation. Although this unit is ascribed a Middle Pleistocene date, it formed prior to the first advance of the Scandinavian ice sheet to the British Isles (Lee, 2009) (Table 1). The predominance of resistant heavy minerals (kyanite, rutile, tourmaline, staurolite) is typical of preglacial deposits. It is assumed that the Cromer Forest-bed Formation records a fluvial system that was $100-250 \mathrm{~km}$ long and drained outcrops of terrigenous rocks, mainly of Mesozoic age, located along the southeastern margin of the Pennines (Fig.
9). The overlying Middle Pleistocene deposits are genetically connected with glacial supply. Therefore their mineral spectrum is different, i.e., 'fresh$\mathrm{er}^{\prime}$ and with fewer resistant heavy minerals. The English case is thus analogous to the one in central Poland where heavy mineral analysis allows to establish a relatively precise upper boundary of the non-glacial Pleistocene. These parallels are linked to the quite similar bedrock geology of the southern Pennines and northern Holy Cross Mountains, except for one difference: Carboniferous terrigenous rocks build the highest parts of the English preglacial catchments, but such are missing from the Holy Cross Mts. However, Mesozoic lithostratigraphical successions in both regions are nearly identical. Preglacial fluvial arteries in England and Poland flowed across the following formations: terrigenous rocks of the Upper Triassic, Lower and Middle Jurassic, carbonates of the Upper Jurassic, sandstones of the Lower Cretaceous and, finally, limestones and marls of the Upper Cretaceous. As can be seen, in both cases sedimentary terrigenous rocks (i.e., the source of heavy minerals) are numerous and lithologically adequate.

The foregoing comparisons show that sites of preglacial deposits in central Poland belong to the few European regions where rivers redeposited material from sedimentary terrigenous rocks of the Neogene/Pleistocene transition. Consequently, preglacial alluvia are 'mature', i.e., contain both rocks and minerals that are highly resistant to physical and chemical weathering (Fig. 10). For this reason petrographical and mineralogical analyses are 


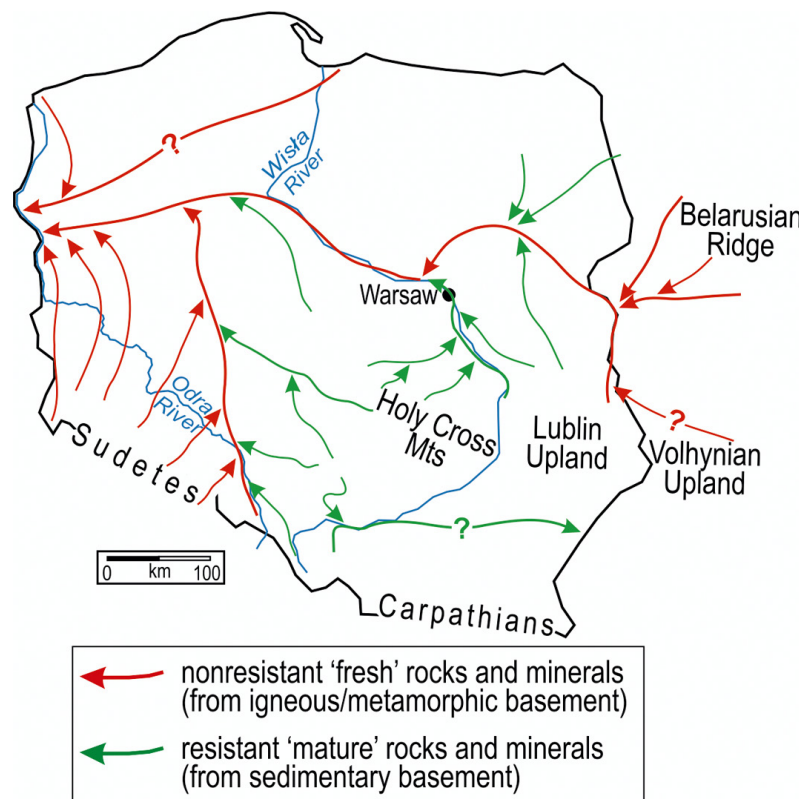

Fig. 10. Pliocene to Early Pleistocene fluvial palaeogeography of the Polish territory (based on Dyjor, 1987b; Lewandowski \& Kaziuk, 1982; Badura \& Przybylski, 2004; Piwocki et al., 2004, with author's modification). Preglacial alluvia in the central Polish basin contain resistant heavy mineral assemblages and are therefore well distinguished from glaciofluvial deposits of Middle Pleistocene age.

a good tool to distinguish old preglacial formations from younger glacial ones within Pleistocene successions. On the other hand, the same criteria fail in numerous other areas across Europe where material from igneous/metamorphic rocks was redeposited into fluvial strata of Early Pleistocene age.

Moreover, it is worth emphasising that current research suggests highly stable palaeogeographical conditions in central-eastern Europe. The main arteries of fluvial systems (ancient valleys) remained the same since the Pliocene, even commonly since the Middle Miocene, up to the Middle Pleistocene (compare Dyjor, 1987, 1991; Badura \& Przybylski, 2004; Piwocki et al., 2004; Knox et al., 2010). Afterwards, the first advance of the Scandinavian ice sheet led to a marked change in the fluvial network.

\section{Conclusions}

Heavy-mineral analysis is a criterion that is frequently used in stratigraphical differentiation between the non-glacial Early Pleistocene (so-called preglacial) and glacial Middle Pleistocene. This is due to the fact that a lithological change at this boundary is vague or most often lacking. The fluvial deposits of Early Pleistocene age usually are underlain by Neogene sands, as well as overlain by glaciofluvial ones of Middle Pleistocene age.

The occurrence of non-resistant heavy minerals (amphiboles, pyroxenes, epidotes, olivines, apatites) is recognised as an indicator of the first glaciation. These minerals are genetically connected with igneous and metamorphic rocks that were supplied by the ice sheet from the Scandinavian Shield to the basins studied here.

Heavy mineral analysis is a useful stratigraphical tool at those sites within the catchments where terrigenous rocks form the basement of Neogene and Lower Pleistocene deposits. Such situations are infrequent in Europe, but can be found, for example, in central Poland or central-eastern England. In both cases the parent material for fluvial redeposition during the Neogene and later, during the Early Pleistocene, were most probably Cretaceous sandstones and perhaps Jurassic sandstones as well. Such repeated reworking led to specific assemblages of heavy minerals that are highly resistant to weathering such as zircon, rutile, tourmaline, staurolite, kyanite and andalusite.

Most often, European fluvial systems of Neogene and Early Pleistocene age acted in the vicinity of outcrops of igneous and/or metamorphic rocks. There are numerous examples: pre-Rhine, pre-Weser, pre-Elbe, pre-Odra and the main Neogene river in Europe, the Baltic River. In all these cases, alluvia contain non-resistant heavy minerals, showing that the importance of mineralogical tools in stratigraphical interpretations is limited.

In European lowlands, Neogene fluvial systems were still active during the Early Pleistocene. Therefore, the river network was stable between 6 to 0.8 myr ago.

\section{References}

Antoine, P., Moncel, M.-H., Locht, J.-L., Limondin-Lozouet, N., Auguste, P., Stoetzel, E., Dabkowski, J., Voinchet, P., Bahain, J.-J. \& Falgueres, C., 2015. Dating the earliest human occupation of Western Europe: New evidence from the fluvial terrace system of the Somme basin (Northern France). Quaternary International 370, 77-99.

Arnold, L.J., Demuro, M., Parés, J.M., Pérez-González, A., Arsuaga, J.L., Bermúdez de Castro, J.M. \& Carbonell, E., 2015. Evaluating the suitability of extended-range luminescence dating techniques over early and Middle Pleistocene timescales: Published datasets and case studies from Atapuerca, Spain. Quaternary International 389, 167-190.

Badura, J. \& Przybylski, B., 2004. Evolution of the Late Neogene and Eopleistocene fluvial system in the fore- 
land of the Sudetes Mountains, SW Poland. Annales Societatis Geologorum Poloniae 74, 43-61.

Bateman, R.M. \& Catt, J.A., 2007. Provenance and palaeoenvironmental interpretation of superficial deposits, with particular reference to post-depositional modification of heavy mineral assemblages. In: Developments in Sedimentology 58, 151-188.

Bijlsma, S., 1981. Fluvial sedimentation from the Fennoscandian area into the North-West European Basin during Late Cenozoic. Geologie en Mijnbouw 60, 337345.

Boenigk, W. \& Frechen, M., 2006. The Pliocene and Quaternary fluvial archives of the Rhine system. Quaternary Science Reviews 25, 550-574.

Bolikhovskaya, N.S., Faustov, S.S. \& Markova, A.K., 2016. Pleistocene climatic stratigraphy and environments of the Terek-Kuma Lowland (NW Caspian sea region) inferred from palynological, paleomagnetic and rodent records of the long Otkaznoye sediment sequence. Quaternary International 409, 16-32.

Bujak, L. 2010. Heavy minerals in preglacial sediments of the southern Mazovian Lowland. Biuletyn Państwowego Instytutu Geologicznego 438, 19-32.

Bujak, Ł., Woronko, B., Winter, H., Marcinkowski, B., Werner, T., Stachowicz-Rybka, R., Żarski, M., Woźniak, P.P. \& Rosowiecka, O., 2016. A new stratigraphic position of some Early Pleistocene deposits in central Poland. Geological Quarterly 60, 238-251.

Chiarini, E., Giardini, M., Mattei, M., Papasodaro, F., Porreca, M. \& Sadori, L., 2009. Plio-Quaternary geological evolution of the high Salto river valley (Central Italy): The Marano de' Marsi unit. Alpine and Mediterranean Quaternary 22, 325-343.

Ciuk, E., 1970. Schematy litostratygraficzne trzeciorzędu Niżu Polskiego [Lithostratigraphical schemes of the Tertiary from the Polish Lowland area]. Kwartalnik Geologiczny 14, 754-771.

Cordier, S., Harmand, D., Lauer, T., Voinchet, P., Bahain, J.-J. \& Frechen, M., 2012. Geochronological reconstruction of the Pleistocene evolution of the Sarre valley (France and Germany) using OSL and ESR dating techniques. Geomorphology 165-166, 91-106.

Czerwonka, J.A. \& Krzyszkowski, D., 2001. Preglacial (Pliocene - Early Middle Pleistocene) deposits in Southwestern Poland: lithostratigraphy and reconstruction of drainage pattern. In: Krzyszkowski, D. (Ed.): Late Cainozoic Stratigraphy and Palaeogeography of the Sudetic Foreland. Wind, Wrocław, 147-195.

Donders, T.H., Kloosterboer-van Hoeve, M.L., Westerhoff, W., Verreussel, R.M.C.H \& Lotter, A.F., 2007. Late Neogene continental stages in NW Europe revisited. Earth-Science Reviews 85, 161-186.

Duval, M., Sancho, C., Calle, M., Guilarte, V. \& Peña-Monné, J.L., 2015. On the interest of using the multiple center approach in ESR dating of optically bleached quartz grains: Some examples from the Early Pleistocene terraces of the Alcanadre River (Ebro basin, Spain). Quaternary Geochronology 29, 58-69.

Dyjor, S., 1987a. Systemy kopalnych dolin Polski Zachodniej i fazy ich rozwoju $\mathrm{w}$ młodszym neogenie $\mathrm{i}$ eoplejstocenie [Systems of burried valleys in western
Poland and phases of their development in the Upper Neogene and Eopleistocene]. [In:] Jahn, A. \& Dyjor, S. (Eds): Problemy młodszego neogenu i eoplejstocenu w Polsce [Problems of Late Neogene and Eopleistocene in Poland] . Ossolineum, Wrocław, p. 85-101 (in Polish with English summary).

Dyjor, S., 1987b. Młodotrzeciorzędowy i eoplejstoceński rozwój sieci kopalnych dolin w Polsce na tle ewolucji paleogeograficznej obszaru bruzdy środkowoeuropejskiej [Early Tertiary and Eopleistocene evolution of burried valleys in Poland against the background of the Middle European palaeogeography. [In:] Jahn, A. \& Dyjor, S. (Eds): Problemy mtodszego neogenu $i$ eoplejstocenu w Polsce [Problems of Late Neogene and Eopleistocene in Poland] . Ossolineum, Wrocław, p. 85-101 (in Polish with English summary).

Dyjor, S., 1991. Wpływ ewolucji paleogeograficznej na rozwój zlodowaceń w Polsce Zachodniej [Influence of the palaeogeographical evolution on the development of glaciations in western Poland]. [In:] Kostrzewski, A. (Ed.): Geneza, litologia i stratygrafia utworów czwartorzedowych [Genesis, lithology and stratigraphy of Quaternary deposits]. Geografia, Poznań, 50, p. 419-433 (in Polish with English summary).

Gao, H.S., Li, Z.M., Liu, X.F., Pan, B.T., Wu, Y.J. \& Liu, F.L., 2017. Fluvial terraces and their implications for Weihe River valley evolution in the Sanyangchuan Basin. Science China Earth Sciences 60, 413-427.

Gibbard, P.L. \& Lewin, J., 2016. Partitioning the Quaternary. Quaternary Science Reviews 151, 127-139.

Griffioen, J., Klaver, G. \& Westerhoff, W.E., 2016. The mineralogy of suspended matter, fresh and Cenozoic sediments in the fluvio-deltaic Rhine-Meuse-ScheldtEms area, the Netherlands: An overview and review. Netherlands Journal of Geosciences 95, 23-107.

Goździk, J. \& Zieliński, T., 2017. Evolution of Early Pleistocene fluvial systems in central Poland prior to the first ice sheet advance - a case study from the Bełchatów lignite mine. Geologos 23, 89-107.

Goździk, J., Kenig, K. \& Skórzak, A., 2010. Zmiany kształtu ziaren kwarcowych oraz składu mineralnego piaszczystych osadów miocenu, pliocenu i niższego czwartorzędu w rowie Kleszczowa [Changes in the shape of quartz grains and mineral composition of Miocene, Pliocene and Lower Quaternary sand deposits in the Kleszczów Graben]. Biuletyn Państwowego Instytutu Geologicznego 438, 33-50.

Kemna, H.A., 2008. Pliocene and Lower Pleistocene fluvial history of the Lower Rhine Embayment, Germany: Examples of the tectonic forcing of river courses. Quaternary International 189, 106-114.

Knox, R.W.O.B., Bosch, J.H.A., Rassmussen, E.S., Heilmann-Clausen, C., Hiss, M., De Jugt, I.R., Kasiński, J., King, C., Köthe, A., Słodkowska, B., Standke, C. \& Vandenberghe, M., 2010. Cenozoic. In: Doornenbal \& Stevenson, A. (Eds): Petroleum Geological Atlas of the South Permian Basin Area. EAGE Publication, Houten, 211-224.

Kosmowska-Ceranowicz, B., 1979. Zmienność litologiczna i pochodzenie okruchowych osadów trzeciorzędowych wybranych rejonów północnej i środkowej Pol- 
ski [Lithology and origin of Tertiary clastic deposits in central and northern Poland: results of translucent heavy-mineral analysed]. Prace Muzeum Ziemi 30, 3-73.

Krzyszkowski, D., 1990. Neogene fluvial sedimentation in the Kleszczów Graben, Central Poland. Journal of Sedimentary Petrology 63, 204-217.

Krzyszkowski, D. \& Winter, H., 1996. Stratigraphic position and sedimentary features of the Tertiary Uppermost Fluvial Member in the Kleszczów Graben, Central Poland. Annales Societatis Geologorum Poloniae $66,17-33$

Lee, J.R., 2009. Patterns of preglacial sedimentation and glaciotectonic deformation within early Middle Pleistocene sediments at Sidestrand, north Norfolk, UK. Proceedings of the Geologists' Association 120, 34-48.

Lewandowski, J. \& Kaziuk, H., 1982. Ewolucja kopalnej sieci rzecznej region śląsko-krakowskiego [Ancient Early Pleistocene valleys in the Silesian-Cracow region]. Geological Quarterly 26, 177-190 (in Polish with English summary).

Lewiński, J., 1928. Utwory preglacjalne i glacjalne Piotrkowa i okolic [Preglacial and glacial deposits of Piotrków and surroundings]. Sprawozdania z posiedzeń Towarzystwa Naukowego Warszawskiego, Wydz. III 21, 49-66.

Mahnac, A.A. (Ed.), 2002. Geology and natural resources. In: National Atlas of Belarus. Minsk, pp. 35-60.

Marcinkowski, B. \& Mycielska-Dowgiałło, E., 2013. Heavy-mineral analysis in Polish investigations of Quaternary deposits: a review. Geologos 19, 5-24.

Marks, L., Dzierżek, J., Janiszewski, R., Kaczorowski, J., Lindner, L., Majecka, A., Makos, M., Szymanek, M., Tołoczko-Pasek, A. \& Woronko, B., 2016. Quaternary stratigraphy and paleogeography of Poland. Acta Geologica Polonica 66, 403-427.

McCann, T. (Ed.), 2008. The Geology of Central Europe. Vol. 2: Mesozoic and Cenozoic. The Geological Society, London. 1538 pp.

Mojski, J.E., 2005. Ziemie polskie w czwartorzędzie [Polish area in Quaternary]. Polish Geological Institute, Warszawa, $404 \mathrm{pp}$.

Piwocki, M. \& Ziębińska-Tworzydło, M., 1997. Neogene of the Polish Lowlands - lithostratigraphy and pollen-spore zones. Kwartalnik Geologiczny 41, 21-40.

Piwocki, M., Badura, J. \& Przybylski, B., 2004. Neogen [Neogene]. In: Peryt, T.M. \& Piwocki, M. (Eds): Geology of Poland. Stratigraphy. Cenozoic. Paleogene, Neogene. Polish Geological Institute, Warszawa, 71-133.

Pirkle, F.L., Pirkle, W.A., Pirkle, E.C., Rich, F.J., Spangler, D.P. \& Pirkle, D.L., 2013. Depositional environment of the heavy-mineral deposits of Bailey, North Carolina, U.S.A. Southeastern Geology 49, 145-178.
Racinowski, R., 2010. Główne przezroczyste minerały ciężkie w osadach czwartorzędowych Polski [Main transparent heavy minerals in Quaternary deposits]. Biuletyn Państwowego Instytutu Geologicznego 438, 99106.

Roman, M., 2010. Preglacjalne osady rzeczne ze stanowiska Baruchowo (Kotlina Płocka) [Preglacial flvial deposits in the Baruchowo site (Płock Basin)]. Biuletyn Państwowego Instytutu Geologicznego 438, 107-122.

Roquero, E., Silva, P.G., Goy, J.L., Zazo, C. \& Massana, J., 2015. Soil evolution indices in fluvial terrace chronosequences from central Spain (Tagus and Duero fluvial basins). Quaternary International 376, 101-113.

Sarnacka, Z., 1978. Plejstocen rejonu doliny Wisły między Magnuszewem i Górą Kalwarią [Pleistocene of the Wisła River valley between Magnuszew and Góra Kalwaria]. Biuletyn Instytutu Geologicznego 300, 5-96.

Stuchlik, L., 1987. Przegląd badań paleobotanicznych osadów plioceńskich i wczesnoplejstoceńskich Polski środkowej i południowej [Palaeobotanical studies of Pliocene and Early Pleistocene deposits in middle and southern Poland - review]. In: Jahn, A. \& Dyjor, S. (Eds): Problemy młodszego neogenu i eoplejstocemu w Polsce [Problems of Late Neogene and Eopleistocene in Poland]. Ossolineum, Wrocław, 53-63.

Szujó, G.L., Sebe, K., Sipos, G. \& Pozsgai, E., 2017. Pleistocene fluvial gravel in the Villány Hills (SW Hungary). Foldtani Kozlony 147, 85-98.

Westerhoff, W.E., Kemna, H.A. \& Boenigk, W., 2008. The confluence area of Rhine, Meuse, and Belgian rivers: Late Pliocene and Early Pleistocene fluvial history of the northern Lower Rhine Embayment. Netherland Journal of Geosciences 87, 107-125.

Westgate, J.A., Pearce, G.W., Preece, S.J., Schweger, C.E., Morlan, R.E., Pearce, N.J.G. \& Perkins, T.W., 2013. Tephrochronology, magnetostratigraphy and mammalian faunas of Middle and Early Pleistocene sediments at two sites on the Old Crow River, northern Yukon Territory, Canada. Quaternary Research 79, 75-85.

Widera, M., 2007. Litostratygrafia i paleotektonika kenozoiku podplejstoceńskiego Wielkopolski [Lithostratigraphy and palaeotectonics of the sub-Pleistocene Cenozoic of Wielkopolska]. Adam Mickiewicz University Press, Poznań, 223 pp.

Widera, M., Kowalska, E. \& Fortuna, M., 2017. A Miocene anastomosing river system in the area of Konin lignite mine, central Poland. Annales Societatis Geologorum Poloniae $87,157-168$.

Manuscript submitted 10 November 2017 Revision accepted 25 April 2018 